Rev. Marcelo Javier Navarro Muñoz ${ }^{1}$

https://orcid.org/0000-0002-6878-0723; 15010329@hope.ac.uk

Liverpool Hope University

\title{
Faith - Reason: a Problematic Relationship? Theology as an Extension of Faith in Reason
}

\begin{abstract}
In this article the author reviews the interrelationship between faith and reason in the steps of John Paul II's Encyclical Letter Fides et ratio. He explores briefly historical circumstances following Etienne Gilson. Then, he introduces philosophical and theological considerations of Cornelio Fabro to do theology in the footsteps of Aquinas. From the perspective of Thomism of the Italian philosopher and by recalling the most urgent theological tasks for the third millennium as indicated in Fides et ratio, the author presents general guidelines for the circularity of faith and reason within the context of fundamental theology. Throughout this article he reads Fides et ratio specifically through the Fabrian lens to present a fresh perspective as a contribution to fundamental theology. Finally, he recalls the conclusive recommendation of John Paul II in the aforementioned letter so as to harmonize reason and faith within a Marian framework.
\end{abstract}

Keywords: faith, reason, Thomism, fundamental theology

\section{Streszczenie}

Wiara - rozum: problematyczna relacja?

Teologia jako przedłużenie wiary w rozumie

Autor dokonuje przeglądu wzajemnych relacji między wiarą a rozumem w świetle encykliki Jana Pawła II Fides et ratio. Za Etienne Gilsonem omawia pokrótce uwarunkowania historyczne. Następnie przedstawia niektóre filozoficzne

1 Rev. Marcelo Javier Navarro Muñoz, IVE - is a professed member of the Institute of the Incarnate Word living in Fossanova Abbey (Italy); professor of Fundamental Theology at the Venerable Archbishop Fulton Sheen House of Formation in Maryland (US). Ph.D. at Maryvale Institute (Birmingham, UK) and Liverpool Hope University in 2020; doctoral thesis: The Epistemological Structure of the Act of Faith. The Contribution of the Intensive Thomism of Cornelio Fabro to Fundamental Theology. 
i teologiczne rozważania Cornelio Fabra na temat uprawiania teologii śladami Akwinaty. Z perspektywy tomizmu włoskiego filozofa, przywołując najpilniejsze zadania teologiczne na trzecie tysiąclecie wskazane w Fides et ratio, autor przedstawia ogólne wytyczne dotyczące cyrkularności wiary i rozumu w kontekście teologii fundamentalnej. W całym artykule odczytuje Fides et ratio szczególnie przez pryzmat nauczania Cornelio Fabra, aby dać świeży wkład do teologii fundamentalnej. Na koniec autor przypomina rozstrzygające zalecenie Jana Pawła II zawarte we wspomnianym liście, aby zharmonizować rozum i wiarę w ramach maryjnych.

Słowa kluczowe: wiara, rozum, tomizm, teologia fundamentalna

\section{Brief introduction to the "long and troubled history" of the relationship of reason and faith ${ }^{2}$}

Why has the relationship between reason and faith been problematic? To answer this question, I first present the relationship reason-faith in the footsteps of the general guidelines offered by FR. ${ }^{3}$ I then introduce the topic through the historical analysis of Etienne Gilson, thereby advancing the standpoint of the Italian philosopher Cornelio Fabro, both considered essential Thomists. From the perspective of the essential (or intensive) Thomism of Cornelio Fabro I approach FR 67, which contains a clear description of what concerns fundamental theology. ${ }^{4}$ Thus, by exploring one possible way to do theology, ${ }^{5}$ specifically fundamental theology, I indicate some general guidelines for doing theology, which I will

2 "The debate over the interrelationships and mutual priorities of faith and reason has a long and troubled history" (N.Ormerod, Faith and Reason: Perspectives from MacIntyre and Lonergan, "The Heythrop Journal" 46 (2005) no. 1, p. 11).

3 John Paul II, Encyclical Letter Fides et Ratio. On the Relationship between Faith and Reason, Boston 1998 (=FR). Chapter IV of FR is entirely dedicated to the relationship between faith and reason, nn. 36-48: it "offers a magisterial reading key of the history of the relationship between faith and reason. This chapter also has a linking function to the following [chapters] as it operates the passage from the topic of the relationship faith/reason to that of the relationship theology/philosophy, which will be developed in greater detail in chapters $\mathrm{V}$ and VI, from the point of view of that which is at the heart of the Magisterium of the Church" (A. Strumia, La fede e il risanamento della ragione come ragione, "Divus Thomas" 108 (2005) no. 1, p. 156).

${ }_{4}$ "With its specific character as a discipline charged with giving an account of faith (cf. 1 Pet 3:15), the concern of fundamental theology will be to justify and expound the relationship between faith and philosophical thought" (FR 67 \$1).

5 FR $43 \S 3$. 
highlight throughout this study. Finally, after a concise analysis of the problematic (or not) nature of the relationship between reason and faith, I summarize the leading principles for the fundamental theological speculation within the faith-reason relationship.

For Fabro, theology is an extension of faith in reason. In 1979 he recalled that the second Vatican Council, in two of its documents, pointed to Aquinas as "the guide to operate the encounter of faith and reason." 6 For FR faith is "an exercise of thought" and human reason does not disappear "in assenting to the contents of faith". John Paul II claimed that the Church "has been justified in consistently proposing St. Thomas as a master of thought and a model of the right way to do theology." In this paper I explore briefly how to do fundamental theology inspired by both John Paul II and Cornelio Fabro.

\subsection{Faith and Reason in Fundamental Theology}

We can affirm tout court that our discipline, Catholic Fundamental Theology, has undergone vast changes throughout the twentieth century. The landscape of fundamental theology continues to develop even as we write, to which testify the many current endeavors that are taking place. Abundant secondary literature shows the genuine interest in the development of this theological discipline ${ }^{8}$ and the labor of fundamen-

6 C. Fabro, Le Ragioni del Tomismo. Dopo il Centenario dell'Enciclica "Aeterni Patris", eds. A. Livi, C. Fabro, F. Ocáriz, C. Vansteenkiste, Milano 1979, p. 52-53.

7 FR 43 \$2 and \$3. John Paul II referred also to the "particular place" of Aquinas in the development of the process between the knowledge of faith and the knowledge of philosophy, "not only because of what he taught but also because of the dialogue which he undertook with the Arab and Jewish thought of his time [...] Thomas had the great merit of giving pride of place to the harmony which exists between faith and reason. Both the light of reason and the light of faith come from God, he argued; hence there can be no contradiction between them” (see FR $42 \S 2$ and $43 \S 1$ ). "The Magisterium’s intention has always been to show how St. Thomas is an authentic model for all who seek the truth. In his thinking, the demands of reason and the power of faith found the most elevated synthesis ever attained by human thought, for he could defend the radical newness introduced by revelation without ever demeaning the venture proper to reason" (FR 78). See also FR 58.

8 For example, Professor Gerald O'Collins published in 2011 Rethinking Fundamental Theology: Toward a New Fundamental Theology (New York 2011) dedicating the first and last 
tal theologians to engage in conversation with (post-) post-modernity, or with the cultural agorae of our times. ${ }^{9}$

A genuine academic interest in fundamental theology can certainly lead to an attentive reading of John Paul II's Encyclical Letter FR. Yet can we discuss the very manner of doing theology from the perspective of fundamental theology? The two tightly packed paragraphs, which the document dedicates to describing the said discipline, provide a useful reading into "the right way to do theology," with fundamental theology as the door for entering into the beautiful complexities of ampler theological speculation. The letter invites the study of "revelation and its credibility, as well as the corresponding act of faith;" thus, "fundamental theology should show how, in the light of the knowledge conferred by faith, there emerge certain truths which reason, from its own independent enquiry, already perceives," and "should demonstrate the profound compatibility that exists between faith and its need to find expression by way of human reason fully free to give its assent”. Faith reinforces reason in its search for ultimate truths. ${ }^{10}$

\subsection{The metaphysical foundation for the relationship between faith and reason}

I argue that the significant compatibility of faith and reason, as per FR 67, provides one of the general guidelines for interpreting their mutual interaction in the search for truth. The document gives a hint

chapters to the nature of fundamental theology, followed up by the article Fundamental theology: The continuing debate, "Pacifica" 27 (2014) n. 1, p. 97-110.

See the monographs of Massimo Epis, César Izquierdo, Salvador Pié-Ninot, Antonio Sabetta, Guy Mansini, and the comprehensive series of fundamental theology by Giuseppe Tanzella-Nitti, among others.

9 For instance, Simone Billeci stresses the importance for fundamental theology to have a dialogical and apologetic role in the complex panorama of the post-modern era characterized by indifference toward God, the rebirth of joyous polytheism, the divinity as an object of play and subjective consumption, and he affirms that the return of a phenomenologically complex and philosophically high profile of the sacred offers fundamental theology an opportunity for revitalization (S. Billeci, La riflessione teologica sulla religione nei principali trattati di Teologia fondamentale, "Ho Theologos" 34 (May 2016) no. 2, p. 249-250).

10 FR 67 §1. Emphases added. 
within the context of the "concern of fundamental theology," namely, that "reason needs to be reinforced by faith;" here is a clear example of a "healthy relationship" between the two. One can find another hint for such fruitful interaction in FR 83: to move "from phenomenon to foundation"- which the encyclical considers an urgent step for facing the challenges of the third millennium - and to keep in mind that "the person constitutes a privileged locus for the encounter with being, and hence with metaphysical enquiry":

We cannot stop short at experience alone; even if experience does reveal the human being's interiority and spirituality, speculative thinking must penetrate to the spiritual core and the ground from which it rises. Therefore, a philosophy which shuns metaphysics would be radically unsuited to the task of mediation in the understanding of revelation. ${ }^{11}$

FR $83 \S 1$ speaks of metaphysics and its corresponding notion six times: "genuinely metaphysical range," the sense in which "metaphysics" should be understood, the human's being capacity to know the "transcendent and metaphysical dimension," "metaphysics" not as an alternative to anthropology, "metaphysics" to ground the person's dignity, and a reference to the person as privileged locus for the encounter with being and "metaphysical enquiry." FR 83 \$2 refers to the "metaphysical dimension of reality" and cautions that "a philosophy which shuns metaphysics would be radically unsuited to the task of mediation in the understanding of revelation;" \$3 speaks of "the essential role of mediation" of "metaphysics" in theological research, and that "a theology without metaphysical horizon" cannot aid the intellectus fidei. Finally, the Pope concludes in $\$ 4$ with the strong insistence "on the metaphysical element" as "the path to be taken." That makes

11 FR 83 \$1 and \$2. The task of a "metaphysical mediation" to understand revelation cannot be but an expression of the solid correspondence between both. A. Strumia speaks of the restoration [risanamento] of reason, using the beautiful analogy of a "sort of 'redemption' of reason, which is 'saved' by faith" (A. Strumia, La fede e il risanamento della ragione come ragione, "Divus Thomas" 108 (2005) no. 1, p. 165), and "a work of 'redemption' of reason and philosophy" (p. 172). In the same article, the author offers clear analysis for the way revelation can orient reason, the Magisterium can provide guidance, and the way rationalism lacks an openness to mystery (p. 167-168). 
eleven mentions of the word metaphysics or its equivalent in about a single small page. ${ }^{12}$

FR 97 refers to the intellectus fidei as turning to the philosophy of being within the "Christian metaphysical tradition," "and the intimate relationship which exists between faith and metaphysical reasoning." This statement is more than just a hint as to the mediation of metaphysics in theological terrain: it delineates their natures and establishes their circular interaction. Again, philosophical (or metaphysical) and theological speculation, is the scientific development of reason and faith.

In the conclusion of FR, John Paul II, who considers theology "the science of faith", claims that the duty of theology is "to recover its true relationship with philosophy" and conversely, "philosophy too should recover its relationship with theology." ${ }^{13}$ When expressing his gratitude "to theologians," the pontiff reminds them of the "intimate bond between theological and philosophical wisdom," one of the "most distinctive treasures" of the Christian tradition "in the exploration of revealed truth." Then, he urges theologians "to recover and express to the full the metaphysical dimension of truth in order to enter into a demanding critical dialogue with both contemporary philosophical thought and with the philosophical tradition in all its aspects, whether consonant with the word of God or not."14

We have arrived at a preliminary conclusion. Throughout FR, John Paul II endorses the use of a philosophy of being and repeatedly stresses the importance of metaphysics to support theological work. As it was clearly stated by Strumia, "[t]he exigency expressed by the Magisterium is, substantially, that of a new philosophical foundation of an objective

12 For the importance of metaphysics among the "current developments in hermeneutics and the analysis of language" as "helpful for the understanding of faith," see FR 84. For the idea of the "end of metaphysics" in today's situation see FR $55 \$ 1$.

13 FR 101 §1 and §2.

14 FR 105 §1. Last emphasis mine. FR 106 \$1 requires from philosophers and teachers of philosophy to have the courage to recover "the range of authentic wisdom and truthmetaphysical truth included-, which is proper to philosophical enquiry." 
metaphysics and of a realist epistemology." ${ }^{15}$ This principle, viewed with a Fabrian lens, means that "the work of the reason of a theologian who reflects on the principles of faith is monitored and guided by the supreme magisterium of the Church, which is the visible bond of the unity of the Mystical Body."16

\section{For what is wisdom indeed, if not the rational understanding of faith? ${ }^{17}$}

\subsection{Gilson: reason and revelation in the Middle Ages}

Etienne Gilson's Reason and Revelation in the Middle Ages considers in three concise chapters the primacy of faith, the primacy of reason, and the harmony of reason and revelation. After a short reference to the "three main periods in the development of Western thought" - Greek philosophy, the Middle Ages, and "the new era of purely positive and rational speculation"-Gilson discusses "the main spiritual families" that provided abundant speculative philosophical and theological literature in the Middle Ages ${ }^{18} \mathrm{He}$ identifies these families historically by the different ways they treat the relationship between faith and reason. The first family stands against philosophy; in Gilson's paraphrase,"since God has spoken to us, it is no longer necessary for us to think." 19 The second family is "more enlightened" and its "untiring efforts to blend religious faith with rational speculations" find its best exponent in saint Augustine. ${ }^{20}$

15 A. Strumia, La fede, p. 157. For a return to metaphysics in A. MacIntyre in consonance with FR, and the differences with Lonergan, see N. Ormerod, Fides et Ratio, p. 19 and 21.

16 C. Fabro, Introduzione a San Tommaso. La metafisica tomista e il pensiero moderno, Segni (RM) 2016, p. 76.

17 E. Gilson, Reason and Revelation in the Middle Ages, New York 1938, p. 28.

18 E. Gilson, Reason and Revelation in the Middle Ages, p. 3-5. We do not study here these 'families' or their implications; yet their mention serves as a helpful illustration: the 'Tertullian' family (p. 5-15), the 'Augustinian' family (15-33), and the "Thomist" family (81 et al.).

19 E. Gilson, Reason and Revelation in the Middle Ages, p. 6. One characteristic element of this type is "an absolute opposition between religious faith in the word of God and the use of natural reason in matters pertaining to Revelation" (p. 11).

20 E. Gilson, Reason and Revelation in the Middle Ages, p. 16. "Augustine was never to forget that the safest way to reach truth is not the one that starts from reason and then goes 
The Thomists represent the final position, who "grant that there is a true Revelation: the Christian Revelation. They grant it, but they do not take it for granted." ${ }^{11}$

According to Gilson, "theologism" claims "that every part of Revelation should be understood," while for rationalism "no part of Revelation can be understood." Thus, "[t] he historical significance of Saint Thomas Aquinas rests with the fact that he was the first medieval thinker to go to the root of the difficulty," which was "a problem of order."22

\subsection{The problematic and the path to solution}

This depiction of the problematic also contains the path to solution. Easier said than done, but in the mind of FR this requires a philosophy of being of "genuinely metaphysical range [...] in order to attain something absolute, ultimate and foundational in its search for truth," and which the letter identifies as the third requirement of philosophy (FR 83 \$1). The first is that so as to be consonant with the word of God philosophy recover "its sapiential dimension," (FR 81 \$3) and the second that it verify the human capacity for knowledge of objective truth (FR 82 \$1). For Fabro, here in harmony with Gilson, this is possible due to the distinction between the fields of reason and faith in Aquinas (see fn. 26). If there is a clear distinction of the two orders, then, there unravels more naturally a relationship between faith and reason and their scientific development "best construed

on from rational certitude to faith, but, on the contrary, the way whose starting point is faith and then goes on from Revelation to reason" (p. 17).

21 E. Gilson, Reason and Revelation in the Middle Ages, p. 81.

22 E. Gilson, Reason and Revelation in the Middle Ages, p. 69-70: "the order of what we believe and the order of what we know" (p. 70). The "perfect intellectual modesty" of Thomas combined with his "almost reckless intellectual audacity" allowed him to provide a solution. Gilson says that for Thomas "the specific distinction [...] between faith and rational knowledge was not understood by him as a separation" nor opposition (p. 78). If "the trouble was that some theologians wanted to theologize in philosophy, whereas some philosophers wanted to philosophize in theology" (p. 72), Aquinas can be looked at as a model to do theology since he handled "philosophical problems as a philosopher and theological problems as a theologian" (E. Gilson, Reason and Revelation in the Middle Ages, p. 72). 
as a circle" to which FR 73 refers, nevertheless, distinction does not mean separation. ${ }^{23}$

According to FR, Thomas used "courage of the truth," "freedom of spirit in confronting new problems," and "intellectual honesty" to give "the kernel of the solution [...] to the new encounter of faith and reason," that is, "a reconciliation between the secularity of the world and the radicality of the Gospel." ${ }^{24}$ I believe that we have quickly arrived at a clear characterization of the problem without oversimplifying it. Gilson below provides a good conclusion to these prefatory remarks:

If [...] we learn from medieval theologians what is faith in an objective philosophical knowledge, we shall find ourselves possessed of both Revelation and a Reason. There then will be something to harmonize, and anyone attempting to do it will end at last in meeting the real problem. But he can scarcely avoid meeting Saint Thomas Aquinas. ${ }^{25}$

\section{The act of faith originates directly from the motion of grace; thus, the relationship of faith and reason has an intrinsically dialectical significance ${ }^{26}$}

\subsection{Fabro and the "theoretical significance" of faith and reason}

Fabro indicates that "faith presupposes a precise comportment towards reason" just as philosophy manifests "reason united to the maturity of reflection. In the first moment of the preparation of the act of faith, the hinge of the relationship is faith itself: [...] which is the truth of God to man." Fabro then asserts that the "theoretical significance"

${ }^{23}$ See also S.-T. Bonino OP, Théologie philosophique et intelligence de la foi, conference at the Pontifical University Santa Croce in Rome on November 25, 2016 at https://www. academia.edu (6.11.2020).

24 FR 43 §3.

25 E. Gilson, Reason and Revelation in the Middle Ages, p. 99.

26 C. Fabro, Dio. Introduzione al problema teologico, Segni (RM) 2007, p. 105. Translation mine. The dialectical significance needs be understood within the relationship of grace and nature: on the one hand, the relationship faith-reason "represents and works as a condition or preparation of the acceptance of faith; on the other, that works as consequence of the acceptance of faith itself which is the absolute truth which saves" (C. Fabro, Dio. Introduzione al problema teologico, p. 105). 
of the relationship of faith and reason is that "it assumes the concepts of philosophy to reflect on the formulae of faith and to extend them in their plenitude of truth for conscience, where theology is born."27

Taking a cue from Gilson and FR, we look retrospectively to Aquinas in search of answers. In his Introduzione a San Tommaso, C. Fabro quotes M. D. Chenu and claims that Aquinas placed the principle "of an integral application of the procedures of science to the data of Revelation;" consequently, theology became an "organic discipline in which Scripture, the article of faith" is "the principle known in advance," and from which the work of theology progresses in accord with the laws of the Aristotelian demonstratio. ${ }^{28}$ Under the subtitle The theological method: reason and faith, Fabro shows the interaction of both faculties, basing his analysis on Aquinas:

...the method of theology is principally a recourse to faith, that is the argument of "authority" of divine Revelation which constitutes for the believer the most effective criterion of truth [...] the function of reason, when theology makes recourse to philosophy and to the other human sciences, is of an instrumental nature $[. .$.$] and thus it turns in advantage of reason [...]. { }^{29}$

As A. Nichols notes, a portion from saint Thomas' commentary to second Corinthians describes accurately the interaction between reason and faith since the difference between "knowledge through science and knowledge through faith" is that "science shines only on the mind, showing that God is the cause of everything, that he is one and wise," but

27 C. Fabro, Dio. Introduzione al problema teologico, p. 105-106.

28 C. Fabro, Introduzione a San Tommaso. La metafisica tomista e il pensiero moderno, Segni (RM) 2016, p. 74. Fabro adds, "the Christian theologian must be above all a believer so as to accept, in virtue of the lumen fidei, the truths revealed by God and thus Christian theology differentiates itself from philosophical theology obtained through speculations"(C. Fabro, Introduzione a San Tommaso, p. 74).

29 C. Fabro, Introduzione a San Tommaso, p. 75. It is worth noting that with the distinction "of reason and of faith, saint Thomas opened the possibility of the development of theology as science" and in reference to the theological reflection with the help of "appropriate rational concepts" (p. 76). See also S-Th. Bonino OP, Théologie philosophique for the need of a philosophical theology open to the faith (p. 4), and for the necessity of philosophical theology for the intellectus fidei (p. 8-9). 
"faith enlightens the mind and also warms the affections," thus showing that besides being the first cause God is also savior, redeemer, loving, incarnate. ${ }^{30}$

3.2. It is inadequate to have knowledge without devotion, intelligence without humility, study unsustained by divine grace, and thought without the wisdom inspired by God ${ }^{31}$

Theological manuals with a neo-Scholastic apologetic bent have often, since the early $19^{\text {th }}$ century, received criticism for being "purely defensive, too opportunist or too extrinsecist." ${ }^{32} \mathrm{~A}$ hint for renewing a balanced Thomistic understanding of faith and reason can be found in Fabro's explanation of this criticism of intellectualism, which he deems as inconsistent:

...if in Thomism the first moment is entrusted to the object and therefore to intelligence [...] the second moment is attributed to the subject who is perfected through her or his acts, in the real possession of the object. Therefore, theology is certainly a speculative science, but is virtually also practical: it deals too with human acts, but only inasmuch as "per eos ordinatur homo ad perfectam Dei cognitionem..." ${ }^{33}$

Fabro adds the criterion of "theological sobriety" with which Aquinas treats the existence of the mysteries of faith, the exposition of their content, their proper terms, and the correspondence among the principal

30 A. Nichols OP, Conversation of Faith and Reason. Modern Catholic Thought from Hermes to Benedict XVI, Chicago 2009, p. 12. Emphases added. The citation belongs to Thomas Aquinas, Expositio et lectura super epistolas Pauli Apostoli, Bologna 2006, vol. 3, lectio 3, chapter 2, n. 73, p. 86, corresponding to 2 Cor 2: 14 .

31 See FR $105 \$ 1$. The document cites St. Bonaventure's Itinerarium Mentis in Deum.

32 G. Tanzella-Nitti, La dimensione apologetica della Teologia fondamentale: una riflessione sul ruolo dei preambula fidei, "Annales Theologici" 18 (2007), p. 30. Translation mine. The author cites de Lubac's Apologetique e théologie. For an overview on the manualist approach, see G. Pozzo, La Manualistica, in: Storia della Teologia. Da Vitus Pichler a Henri de Lubac, vol. 3, ed. R. Fisichella, Rome-Bologna 1996, p. 309-336.

33 Fabro, Introduzione, p. 77. Fabro's argument develops around the connection of sanctifying grace with charity, which remains largely tangential for this paper. For a similar appreciation on Aquinas' reputation as intellectualist but more precisely on the act of faith, see A. Nichols OP, Conversation of Faith and Reason, p. 11-12. 
mysteries: for all of them the primary source is divine Revelation..$^{34} \mathrm{FR} 85$, $\S 1$, following the tradition of Popes and the second Vatican Council, reiterates "the conviction that the human being can come to a unified and organic vision of knowledge," which is presented as a task to be taken up "through the next millennium of the Christian era". Fabro's remarks in the conclusion of Dall'essere all'esistente, where he considers the truth of faith as synthesis in act of the person, echo this conviction. The Italian philosopher claims that the oscillation of faith-reason has acquired a "central relevance" in studying the "process of modern thought" and that it has become more urgent to understanding the "human situation" wrought by contemporary thought. He adds:

The perpetual oscillation of philosophy to break the dialectic of faith and reason to absorb one into the other, upon the presupposition that human conscience could "live" two antithetical phases only through a provisional situation, must be considered overcome thanks to the in-depth analysis of the (effective) structure of conscience in its relationship to the real. ${ }^{35}$

For Fabro, a proper understanding of the structure of conscience, synthetic in the act of knowing reality, has overcome this dialectic oscillation. Reason and faith have different objects which belong to different spheres yet are complementary. Faith is an attegiamento di conoscenza a manner of knowledge. Faith "can found knowledge and be founded on knowledge." ${ }^{36}$ Similarly, FR quotes Vatican I's Dogmatic Constitution on the Catholic Faith Dei Filius, chapter IV:

34 A. Nichols OP, Conversation of Faith and Reason, p. 80. In the same manner " $[\mathrm{t}]$ he distinction of the two orders of nature and grace inspires the intimate Thomist Christological argumentation", this distinction could offer a remedy for a healthier, less problematic, relationship between reason and faith. Fabro asserts that the "originality of the work of saint Thomas is therefore in the project, courageously accomplished, of moving the Aristotelian principles within the climate of Christian Revelation" (p. 77). In the context of this article, I read it as an indication of how to do theology -or at least how Aquinas did theologywithout being afraid of a philosophy suitable for such purpose.

35 C. Fabro, Dall'essere all'esistente. Hegel. Kierkegaard, Heidegger e Jaspers, Genoa-Milano 2004, p. 415. Translation mine. The book was first published in 1957.

36 C. Fabro, Dall'essere all'esistente, p. 415. According to Fabro the object of faith is the "conviction of the real", and the object of knowledge in instead the "content" or structure of the real, which presents itself to the different cognitive faculties. "Thus, while the object 
There exists a twofold order of knowledge, distinct not only as regards their source, but also as regards their object. With regard to the source, because we know in one by natural reason, in the other by divine faith. With regard to the object, because besides those things which natural reason can attain, there are proposed for our belief mysteries hidden in God which, unless they are divinely revealed, cannot be known. ${ }^{37}$

\subsection{Circularity in FR and the two poles of theological speculation in Fabro}

Though FR 73 properly refers to the circularity between philosophy and theology, not between faith and reason, the first binary "leads to dialogue between faith and reason." 38 FR 76 \$1, when considering Christian philosophy as one of the stances of philosophy, speaks of "a philosophical speculation conceived in dynamic union with faith." C. Izquierdo indicates that one of the forms of the relationship between philosophy and theology is found "in the dialogue faith-reason which takes place in each believer" particularly among philosophers and theologians. ${ }^{39}$

In this context we can ask: what can be offered to the relationship between reason and faith from the perspective of intensive Thomism? ${ }^{40}$ Fabro considers theology to be "a prolongation of faith in reason and the effort of reason to bring the revealed message within the existent;" he refers to the two planes of the knowledge of God and calls them

of faith touches the existential sphere, the object of pure knowledge -be it sense or intellectbelongs to the formal sphere" (C. Fabro, Dall'essere all'esistente, p. 415).

37 FR 9.

38 C. Izquierdo, The Circular Relationship between Philosophy and Theology: Fides et Ratio 73, "Scripta Theologica" 41 (2009) no. 2, p. 451. Translation mine. FR speaks principally of circular knowledge between philosophy and theology, but these disciplines are the "critical development" of faith and reason according to Izquierdo (p.452), or "the critical development of what is known and what is believed" (p. 455). See a similar observation in A. Nichols, Conversation of Faith and Reason, p. 180.

39 A. Nichols OP, Conversation of Faith and Reason, p. 461.

40 For an overview of Fabro's Thomism see, A. Contat, Le figure della differenza ontologica nel tomismo del Novecento (I), "Alpha Omega" 11 (2008) N. 1, p. 115-128. For Fabro's “modern rethinking of Thomism", see E.C. Fontana, Attualità del Tomismo di Cornelio Fabro, Roma 2007, p. 7-9, and M. Navarro, Father Cornelio Fabro: a model for the renewal of Catholic Theology, "The Incarnate Word" 4 (2017) Issue 2, p. 125-149. 
"two fields of intentionality," reason and faith, whose object is God but considered under different lights and perspectives:

according to the light of reason and the communication of faith, that is according to the double via of access in the mysterium magnum: a double via which opens a double horizon. Above all that of the speculation about the existence and the attributes of God within the sphere of reason; then, that of the divine economy of the divine plane in the history of salvation through the Incarnation in the sphere of faith. ${ }^{41}$

For Fabro there exist two poles of theological speculation, essence and existence, reason and faith, God and man, in connection with nature and faith that theology illumines in its "resolutive function of mediation". He describes the "intentionality of theology" as "the capacity of reason of being illumined and to illumine in contact with faith". He thus explains the notion of transcendence: "God has revealed himself, first in umbra creationis [and] above all in misericordia redemptionis", naming it "transcendence of reference". The "theological phenomenology" of the act of faith" in his own words, becomes an "indispensable propaedeutic" to reestablish in modern men and women "the encounter with faith" and to introduce them into the " discourse of faith' which is theology, without which faith and the act of faith would remain deprived of the point of insertion" in existence. ${ }^{42}$

I argue that if there were no transcendent dimension to refer to, neither could there be a circular relationship, or the circular interaction would become purely immanent. If this were the case, it would undo the theological transcendent dimension concomitantly and preclude the very nature of theology. Some twenty-five years prior to FR the Italian philosopher described circularity, albeit with different terms:

...reason as much as faith do not operate the synthesis of existence but only inasmuch as they are destined to find each other - and therefore to clarify each other in an interchangeable foundation - as the two poles of subjectivity. Only in this

41 C. Fabro, L'avventura della teologia progressista, Segni (RM) 2014, p. 39. Translation mine.

42 C. Fabro, L'avventura della teologia progressista, p. 39-40. 
manner can the two lights occupy the field of conscience to confront each other and to open the ultimate horizon of freedom... ${ }^{43}$

Fundamental theology, by extension, can be considered a discipline that offers (among other things) a theological overview of faith. It extends itself into justifying and expounding the relationship between faith and philosophical thought as its concern according to FR 67. Theology in general is "an understanding of revelation". The main purpose of theology in general, and of fundamental theology as part of it, needs to "mediate the content of faith" to other cultures, hence its "dual task:" "the task of renewing its specific methods in order to serve evangelization more effectively" and the task to "look to the ultimate truth which revelation entrusts to it." ${ }^{44}$

\subsection{Doing Fundamental Theology in the steps of FR and Fabro}

This is not the only manner of doing theology, but it is a path open to the transcendence of the Absolute, and it is based on recent Magisterial teaching. It is one productive way to look at the interrelationship of reason and faith. This incarnational perspective shows how the divine assumes the human without detriment to humanity itself. Grace elevates nature; reason can be elevated by faith. We apply this simple spiritual principle to do theology, which is after all the science of the divine mysteries in search of explanations.

Tracey Rowland says that the relationship of faith and reason is "one of the perennial subjects in the intellectual life of the Church" and cites the statement of Australian theologian Neil Ormerod: "the problem of the interrelationship between faith and reason is complex and tortuous." ${ }^{45}$ Hence, profiting from the work of solid fundamental theologians,

${ }^{43}$ C. Fabro, L'avventura della teologia progressista, p. 39-40. Emphasis mine. Fabro cites Kierkegaard's Papirer in order to suggest that the lights of faith and reason occupy the field of conscience to open to freedom.

${ }^{44} \quad$ FR $92 \S 1$ and $\$ 2$. "The chief purpose of theology is to provide an understanding of revelation and the content of faith" (FR 93).

45 T. Rowland, Catholic Theology, p. 12. The original quotation, "The debate over the interrelationships and mutual priorities of faith and reason has a long and troubled history" is from N. Ormerod, Faith and Reason, p. 11. 
it is possible to search new paths and fresh perspectives within a philosophy of being, rooted in metaphysics, as a legitimate response to the urgent tasks indicated by FR. If faith is an exercise of thought and theology an extension of faith in reason, there should not be contradiction between them; why not, then, let the scientific development of theological faith elevate reason?

The end of chapter six in FR, a chapter dedicated precisely to the interaction between philosophy and theology, affirms that Christian revelation is the point of encounter for both under the guidance of truth, and a point of understanding between believers and non-believers. The document cites saint Augustine, who reminds that believers are also thinkers. ${ }^{46}$ As a future contribution to fundamental theology in consonance with FR, from the perspective of Fabrian Thomism, I may research in another article the attacks of modern thought to Christianity as a historical revealed religion following the three steps that Fabro attributes to rationalism, metaphysical idealism and the resolution of the principle of immanence into atheism. ${ }^{47}$

The reference of FR to the "all-embracing authority" of "Truth, which is Christ," and that "holds out to theology and philosophy alike the prospect of support, stimulation and increase" can be read in the light of circularity. ${ }^{48}$ In answer to what intensive Thomism potentially offers to this relationship "best construed as a circle," and in view of the line

46 "Christian Revelation becomes the true point of encounter and engagement between philosophical and theological thinking in their reciprocal relationship [...] It is again the Fathers who teach us this: "To believe is nothing other than to think with assent... Believers are also thinkers: in believing, they think and in thinking, they believe... If faith does not think, it is nothing". And again: "If there is no assent, there is no faith, for without assent one does not really believe" (FR 79).

47 C. Fabro, Le Ragioni del Tomismo, p. 65-70. Fabro sees the turning upside-down of being (essere) into knowledge (cognoscere), and knowledge into action (agire) at the origin of the criticism of modern thought to Christianity as historical revealed religion (p.65). He speaks strongly of the "obstinate coherence with which modern philosophy has taken in depth the principle of immanence", and how Christian thought needs to find a theoretical point of view to explain how "thought [could] place its own beginning in being, and reason could make the "passage to the Absolute", lest it be trapped in immanentism (p. 69).

${ }_{48} \quad$ FR 92 \$2 quoting Eph 4:15: “...living the truth in love, we should grow in every way into him who is the head, Christ...”. 
of reasoning of this article, I summarize some general guidelines to do fundamental theology:

1) Let grace direct faith; in this way theology is the scientific understanding of faith.

2) Reason can allow faith as a higher principle to guide its search of truth without losing its nature. ${ }^{49}$

3) Always move from phenomenon to (metaphysical) foundation.

4) The relationship of faith and reason has an intrinsically dialectic significance: it is a preparation or condition for the acceptance of faith and as a consequence, faith is the absolute truth that saves.

5) For an existential synthetic approach to the relationship between philosophy and theology, always maintain the circularity of the interchangeable foundation of faith and reason. "Faith founds knowledge and is founded on knowledge. Theology is an extension of faith in reason and reason brings the revealed message within the existent, thus theology is seen as a resolutive function of mediation."

6) Incorporate past and recent knowledge. Theology as an organic discipline needs to search an "organic vision of knowledge" (FR 85 \$1), not a fragmented one. FR identified this as theology's task for the third millennium. Scriptural knowledge can help reason. Theologians are thinkers.

7) Faith and reason confront the real: there is a distinction of orders, but they complement each other.

8) The so-called intellectualist approach of Aquinas is rather a comprehensive dynamic of the structure of object and subject (the person is perfected through her or his own acts in the real possession of the object). These acts are ordained to the perfect knowledge of God. "Faith enlightens the mind and warms the affections."

9) Theology is a speculative and practical science: the knowledge and love of God must lead to salvation. The theological sobriety of Aquinas illumines how to approach the divine mysteries, without dissecting them as if they were merely scientific objects of study.

49 For the interconnected notions of spontaneous and reflexive faith (scientific as religious or theological): natural, historical and supernatural faith, see C. Fabro, Dall'essere all'esistente, p. 416-431. 
10) Theology is the discourse of faith. FR speaks of theological work that responds to a dynamism found in the faith itself.

\section{Conclusion}

If the relationship of faith and reason has a "stormy" past, ${ }^{50}$ a "long and troubled history," and continues to be problematic, a search for a more specific balanced interaction "best construed as a circle" is in order. Studying the greatest realist theological and philosophical minds of ancient and recent past can offer fruitful answers. Throughout this modest article I have read into FR with Fabro in mind, and some other great Thomists to offer a glimpse into a topic as complex as fascinating. I hope it can be a helpful contribution to look at the same old problem from a fresh perspective. Though Fabro was never a fundamental theologian -in fact he was more a philosopher than a theologian- yet he knew how to be inspired by the living principles of Aquinas, whose principles continue to offer solid ground for research..$^{51}$

I would like to add a final remark using the very same allusion made by John Paul II at the end of FR, and project it as the overarching mode of doing theology. Mary is "the table at which faith sits in thought." ${ }^{52}$ Mary is invoked as the Seat of Wisdom, and between her vocation "and the vocation of true philosophy there is a deep harmony." She was called to offer her human being entirely to God, "so too philosophy is called to offer its rational and critical resources that theology, as the understanding of faith, may be fruitful and creative". John Paul II with this stroke of a genius ends this encyclical full of beautiful density, calling to harmonize philosophy and theology, reason and faith, in a Marian

50 A. Nichols referred to the key to a harmonious equilibrium in Ratzinger, which the latter described as "so often stormy" (A. Nichols, Conversation of Faith and Reason, p. 194).

51 The Institute of the Incarnate Word is publishing the critical editions of the complete works of C. Fabro in Italian and English (German and Spanish are forthcoming). For information about the Cornelio Fabro Cultural Project, visit https://www.corneliofabro.org/ en/ and https://www.corneliofabro.org/.

52 FR 108 §1. The citation is from Pseudo-Epiphanius, Homily in Praise of Holy Mary Mother of God: PG 43, 493 as per footnote 132 of FR. 
framework. I believe that this philosophari in Maria is more than mere analogy: it is the right mode of doing theology. ${ }^{53}$

\section{Bibliography}

Aquinas T., Expositio et lectura super epistolas Pauli Apostoli, vol. 3, Bologna 2006.

Billeci S., La riflessione teologica sulla religione nei principali trattati di Teologia fondamentale, "Ho Theologos" 34 (May 2016) no. 2, p. 249-270.

Bonino S-T. OP, Théologie philosophique et intelligence de la foi, pp. 1-10, conference at the Pontifical University Santa Croce in Rome on November 25, 2016 at https:// www.academia.edu (6.11.2020).

Contat A., Le figure della differenza ontologica nel tomismo del Novecento (I), "Alpha Omega" 11 (2008) N. 1, p. 77-129.

Fabro C., Dall'essere all'esistente. Hegel. Kierkegaard, Heidegger e Jaspers, Genoa-Milano 2004.

Fabro C., Dio. Introduzione al problema teologico, Segni (RM) 2007.

Fabro C., Introduzione a San Tommaso. La metafisica tomista e il pensiero moderno, Segni (RM) 2016.

Fabro C., L'avventura della teologia progressista, Segni (RM) 2014.

Fabro C., Le Ragioni del Tomismo. Dopo il Centenario dell'Enciclica "Aeterni Patris", eds. A. Livi, C. Fabro, F. Ocáriz, C. Vansteenkiste, Milano 1979.

Fontana E.C., Attualità del Tomismo di Cornelio Fabro, Roma 2007.

Gilson E., Reason and Revelation in the Middle Ages, New York 1938.

Izquierdo C., The Circular Relationship between Philosophy and Theology: "Fides et Ratio 73", “Scripta Theologica” 41 (2009) no. 2, p. 451-468.

John Paul II, Encyclical Letter Fides et Ratio. On the Relationship between Faith and Reason, Boston 1998.

Karuvelil G., To Whom Am I Speaking? Communication, Culture, and Fundamental Theology, “Theological Studies" 76 (2015) no. 4, p. 675-697.

Navarro M., Father Cornelio Fabro: a model for the renewal of Catholic Theology, "The Incarnate Word Journal" 4 (2017) no. 2, p. 125-149.

Nichols A., OP, Conversation of Faith and Reason. Modern Catholic Thought from Hermes to Benedict XVI, Chicago 2009.

O'Collins G., Rethinking Fundamental Theology: Toward a New Fundamental Theology, New York 2011.

O'Collins G., Fundamental theology: The continuing debate, "Pacifica" 27 (2014) no. 1, p. 97-110.

Ormerod N., Faith and Reason: Perspectives from MacIntyre and Lonergan, "The Heythrop Journal" 46 (2005) no. 1, p. 11-22.

53 Pseudo-Epiphanius, Homily in Praise of Holy Mary Mother of God: PG 43, 493. 
Pozzo G., La Manualistica, in: Storia della Teologia. Da Vitus Pichler a Henri de Lubac, vol. 3, ed. R. Fisichella, Rome 1996, p. 309-336.

Rowland T., Catholic Theology, London-New York 2017.

Strumia A., La fede e il risanamento della ragione come ragione, "Divus Thomas" 108 (2005) no. 1, p. 155-178.

Tanzella-Nitti G., La dimensione apologetica della Teologia fondamentale: una riflessione sul ruolo dei preambula fidei, "Annales Theologici" 18 (2007), p. 11-60.

Tanzella-Nitti G., Proposte e modelli di Teologia Fondamentale nell XX secolo, "Annales Theologici" 24 (2010) no. 1, p. 175-238. 